\title{
DICRANODONTIUM SCHWABEI (BRYOPHYTA, DICRANACEAE) REVISITED: SOME TAXONOMIC AND NOMENCLATURAL CONSIDERATIONS
}

\author{
Halina Bednarek-Ochyra, VÍtĚzSLav PláŠEK \& Ryszard OChyra ${ }^{1}$
}

\begin{abstract}
Dicranodontium schwabei Thér. \& Herzog, a poorly known species from Western Patagonia in Chile, is briefly assessed taxonomically. Some morphological and anatomical details of the species are illustrated and the problems associated with the typification of its name are discussed. The conspecificity of this species and Chorisodontium aciphyllum (Hook.f. \& Wilson) Broth. is confirmed and the geographical distribution and ecology of the latter species is briefly reviewed.
\end{abstract}

Key words: Chile, Chorisodontium, Holodontium, Musci, nomenclature, Patagonia, South America, taxonomy

Halina Bednarek-Ochyra \& Ryszard Ochyra, Department of Bryology, W. Szafer Institute of Botany, Polish Academy of Sciences, ul. Lubicz 46, 31-512 Kraków, Poland; e-mail: h.bednarek@botany.pl

Vitězslav Plášek, Department of Biology and Ecology, University of Ostrava, Chittussiho 10, CZ-710 00 Ostrava, Czech Republic; e-mail: vitezslav.plasek@osu.cz

\section{INTRODUCTION}

Dicranodontium schwabei Herzog \& Thér. was described by Herzog (1939) from a single specimen collected by the Schwabes in Western Patagonia. This author consulted the French bryologist I. Thériot about the status of the original material and he stated that this was a new species of Dicranodontium Bruch \& Schimp., close to the Javanese D. nitidum Dozy \& Molk. [= D. uncinatum (Harv.) A. Jaeger]. The Chilean species is a robust and very handsome moss which is distinct in the anatomy of the costa, the strongly porose lower leaf cells, and distinctly mammillose and rough costa on the abaxial side. These diagnostic characters are clearly illustrated in the protologue. The discovery of this species was remarkable because it was then the second record of the predominantly Holarctic genus Dicranodontium in South America (Greene 1986). The first one was D. asperifolium (Mitt.) Broth. which was originally described by Mitten (1869) from Ecuador and Tatanara in 'Andes Chilenses' which is at present situated in Peru (Frahm 1991). This species is

\footnotetext{
1 Corresponding author
}

currently considered as Campylopus asperifolius Mitt. (Frahm 1981a, 1987).

For over a half century D. schwabei remained an entirely neglected species. Frahm $(1991,1997)$ was the first to provide a comment on its taxonomic status. Having examined the putative type material, he excluded it from the genus Dicranodontium and assigned it to the genus Chorisodontium (Mitt.) Broth., but without indication of its affinities and giving any reasons for this taxonomic conclusion. Although this generic placement is correct in the light of the subsequent assessments of the original collection of D. schwabei, it is questionable whether it was based on an examination of the true type specimen.

\section{TAXONOMY AND NOMENCLATURE}

Dicranodontium schwabei was described on the basis of the single specimen collected in Western Patagonia by G. H. Schwabe and E. Schwabe in the Cerro Tesoro near the village of Puyuhuapi in the province of Aysén (XI Région, Chile) (Fig. 1), whereas Frahm $(1991,1997)$ cited the 


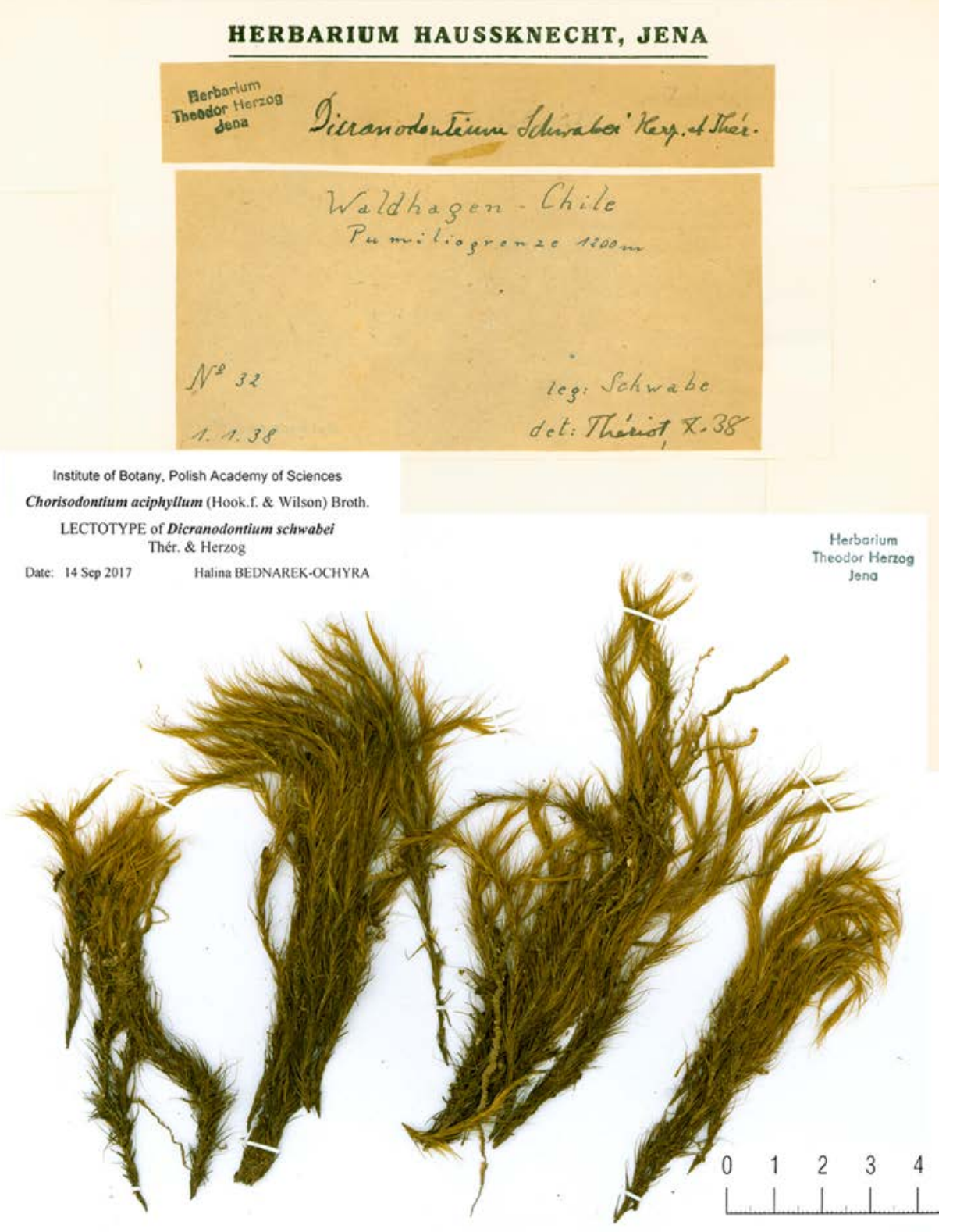

Fig. 1. The label of the lectotype of Chorisodontium aciphyllum (Hook.f. \& Wilson) Broth. (JE).

specimen collected by Grosse in Istmo de Ofqui in Provincia de Aisén as type. It was designated holotype but in the Haussknecht Herbarium in Jena (JE) no material of $D$. schwabei from this locality is available. However, this herbarium does hold a small specimen, consisting of a few shoots only, from Istmo de Ofqui collected by Grosse No. 40 which is determined as Dicranodontium sp. Unfortunately, it does not bear any annotation of J.-P. Frahm. It was examined during the present research and it correctly represents Holodontium strictum (Hook.f. \& Wilson) Ochyra, an austral 
amphiatlantic subantarctic species of the monotypic genus Holodontium (Mitt.) Broth. (Ochyra 1993a). In its overall aspect Holodontium is similar to dicranalean genera and its very broad costa, occupying one third or more of the leaf lamina, with a central row of enlarged guide cells which separate two stereid bands, long-subulate leaves and large alar cells, suggests its close affinity to Campylopus Brid. and Chorisodontium. However, numerous lengthwise cuticular ridges which densely cover the adaxial and abaxial surfaces of the leaf lamina and give them a papillose appearance in transverse section, strongly falcato-secund leaves, often forming penicillate tufts at the tips of shoots, clearly exclude any relationship of the specimen from Istmo de Ofqui with Chorisodontium. Accordingly, the typification of Dicranodontium schwabei by Frahm $(1991,1997)$ has to be superseded. According to Art. 9.19 of the ICN (McNeill et al. 2012), the specimen indicated by this author as the holotype is in serious conflict with the protologue, because it has not been used by Herzog (1939) for description of Ch. schwabei, and its morphological and anatomical traits do not fit the description and illustrations of this species.

A decade later, the original collection of $\mathrm{Di}$ cranodontium schwabei was examined by Müller (2002), who concluded that 'it presents excellent, well developed (plants 5 to $8 \mathrm{~cm}$ high, leaves ca $1.5 \mathrm{~cm}$ long) material of Ch.[orisodontium] aciphyllum'. Because no discussion on the taxonomically important characters of this species is provided, the type material is briefly assessed and illustrated (Fig. 2). Also, no annotation label of this author is available in the specimen of $D$. schwabei in JE. Müller (2002) indicated the specimen examined in the Herzog Herbarium in JE as holotype, although lectotypification would be necessary since then there existed no fewer than two replicates of the type specimen in the Thériot Herbarium in PC and in the Haussknecht Herbarium in JE, but none of them was indicated as type. Nevertheless, Müller's (2002) use of holotype can be considered an error to be corrected for lectotype under Art. 9.9 of the ICN (McNeill et al. 2012). The taxonomic conclusion presented by Müller (2002) is correct, and Dicranodontium schwabei is truly conspecific with
Chorisodontium aciphyllum (Hook.f. \& Wilson) Broth.

Chorisodontium is a small Southern Hemisphere genus, having the main centre of its diversity in South America, with only one species, Ch. aciphyllum, having a wide panholantarctic range (Ochyra et al. 2008). The genus is poorly defined and in fact it is diagnosed only by its bistratose laminal cells at the leaf shoulders and in the leaf subula which gradually fuse with the costa. This gives the impression that the costa is distinctly flaring outwards at the junction of the leaf base and the subula. Externally, Chorisodontium is similar to the genus Campylopus with which it shares the shape and anatomy of the costa, the leaf areolation and the distinct alar cells. The only difference between the two genera is the absence of stomata in Campylopus (always present in Chorisodontium).

Chorisodontium consists of eight species, although in total it included about 30 species and varieties (Wijk et al. 1959, 1969; Frahm 1981b). They are divided into two distinct groups which are isolated geographically. The southern cool-temperate group includes five species that occur primarily in southern South America and occasionally extend to the Subantarctic region, Antarctica and New Zealand (Roivainen \& Bartram 1937; Hyvönen 1991). They are characterised by a very broad costa, shorter leaves with entire or nearly so leaf margins, less distinct alar cells, a deciduous annulus and small unicellular spores, $18-30 \mu \mathrm{m}$ wide, and they are often peat-forming plants. The neotropical group comprises three species which occur at high elevations in the páramo vegetation in the Central and Northern Andes (Frahm 1989; Ochyra 2003). This group is distinct in having larger leaves which are markedly serrate at the apex, a much narrower costa, large alar cells that are often thick-walled and coloured, a persistent annulus and large, often multicellular spores, $20-80 \mu \mathrm{m}$ in diameter, germinating precociously in the capsules.

The plants of the type material of Dicranodontium schwabei are large, to $13 \mathrm{~cm}$ long, and their rigid, straight leaves, to $15 \mathrm{~mm}$ long, immediately attract attention. They are crowded, erect and appressed and, from an oblong-ovate, concave and somewhat clasping base with distinct hyaline to 
brownish alar cells, gradually taper into a long, setaceous, tubulose and involute subula that is straight or somewhat flexuose distally and up to twice as long as the leaf base. The leaves are entire throughout, except for the extreme apex which is sharply or bluntly serrate. The costa is very broad, $300-400 \mu \mathrm{m}$ wide in mid-lamina, and occupies about half the leaf base and the entire subula. It is mostly not sharply defined, pale and concolorous with the laminal cells, and imperceptibly merges with the bistratose lamina at the shoulders and in the subula. In transverse section it is strongly flattened in the basal part and lunate in the subula, and it is internally differentiated into a single central row of enlarged guide cells and conspicuous 3-5-stratose adaxial and abaxial stereid bands and, additionally, it is markedly scabrous at the abaxial side. The laminal cells are smooth throughout, unistratose below and partly bistratose at the shoulders and in the subula. They are rectangular, with moderately thickened and distinctly pitted longitudinal walls, to $15 \mu \mathrm{m}$ wide, and become linear and narrower, to 4-6 $\mu \mathrm{m}$, towards the leaf margins, forming an indistinct border. The distal cells are short-rectangular, rhomboidal to rounded-quadrate, and the alar cells are large, hyaline to brownish and thin-walled, forming a prominent group reaching the costa but easily detached. The type material is sterile.

The large stature of the plants of Dicranodontium schwabei, especially the long-subulate leaves with the awn to about twice longer than the basal portion, clearly suggest that this species is close either to Chorisodontium dicranellatum (Dusén) Roiv. or to Ch. aciphyllum. In the former the adaxial stereid band is mostly 1-2-layered and occasionally a third row of stereids is developed in places. Moreover, Ch. dicranellatum is generally a mediumsized to small plant and its leaves are often falcate. In contrast, Ch. aciphyllum is a very variable species, especially with respect to the size of the plants, length of the leaves, thickness and porosity of the laminal cell walls, and the papillosity of the abaxial surface of the costa and the thickness of the stereid bands. All these characters are extremely variable and are evidently conditioned climatically and environmentally, yet no fewer than 19 various phenotypes of Ch. aciphyllum have been recognised by different authors as separate taxa (Bell 1973, 1977; Hyvönen 1991; Ochyra 1993b, 1994, 1996, 1999). The adaxial stereid band is strong, 4-5-stratose, such as seen in the type material from Hermite Island near Cape Horn (Hooker \& Wilson 1844).

In this context the taxonomic status of Chorisodontium dicranellatum needs re-assessment and it is likely that this species may represent a somewhat depauperate habitat modification of Ch. aciphyllum, as suggested by Hyvönen (1991), who accepted it only provisionally as a species in its own right. Indirect evidence may show it to represent Antarctic populations of Ch. aciphyllum which have developed in extremely harsh climatic conditions. In many Antarctic plants the adaxial stereid bands are weaker than those from the South American mainland and South Georgia and consist of 2-3 and sometimes only a single layer of stereid cells.

The anatomy of the costa, especially the strongly developed stereid bands which consist of mostly 4-5 rows of small cells, clearly shows that Dicranodontium schwabei fits perfectly the typical expression of Ch. aciphyllum and does not deviate much from the type material. Therefore, these two names are rightly considered synonymous, the latter name having priority.

Chorisodontium aciphyllum (Hook.f. \& Wilson) Broth.

Figs $1 \& 2$

in Engl., Nat. Pflanzenfam. Ed. 2, 10: 204. $1924 \equiv D i-$ cranum aciphyllum Hook.f. \& Wilson, London J. Bot. 3: 541. 1844. - Type Citation: Hermite Island, Cape Horn, and Falkland Islands. Lестотуре (vide Bell 1973: p. 35): ' $N^{\circ}$. 123. Dicranum aciphyllum H.fil. \& Wils. Hermite Island, Cape Horn Antarct. Exp. 1839-1843 J.D.H.' - BM-Wilson!; ISOLECTOTYPES: BM-Wilson!, E!, MANCH!; SYNTYPE: '52 Falkl. Islands W. 200 Dicranum aciphyllum Wils.' - BM-Wilson!; ISOSYNTYPES: E!, MANCH!

Dicranodontium schwabei Herzog \& Thér. in Herzog, Beih. Bot. Centralbl. Abt. B, 60: 21. 1939. - TyPe CITATION: [Chile] Westpatagonien: Puyuhuapi, Cerro Tesoro, an der Waldgrenze, auf einem schwach beschatteten Steinblock, ca. 1200 m, leg. Schwabe, n. 32. LectoTYPE (vide Müller 2002: 446 as holotype): 'Herbarium Haussknecht, Jena Herbarium Theodor Herzog Jena 

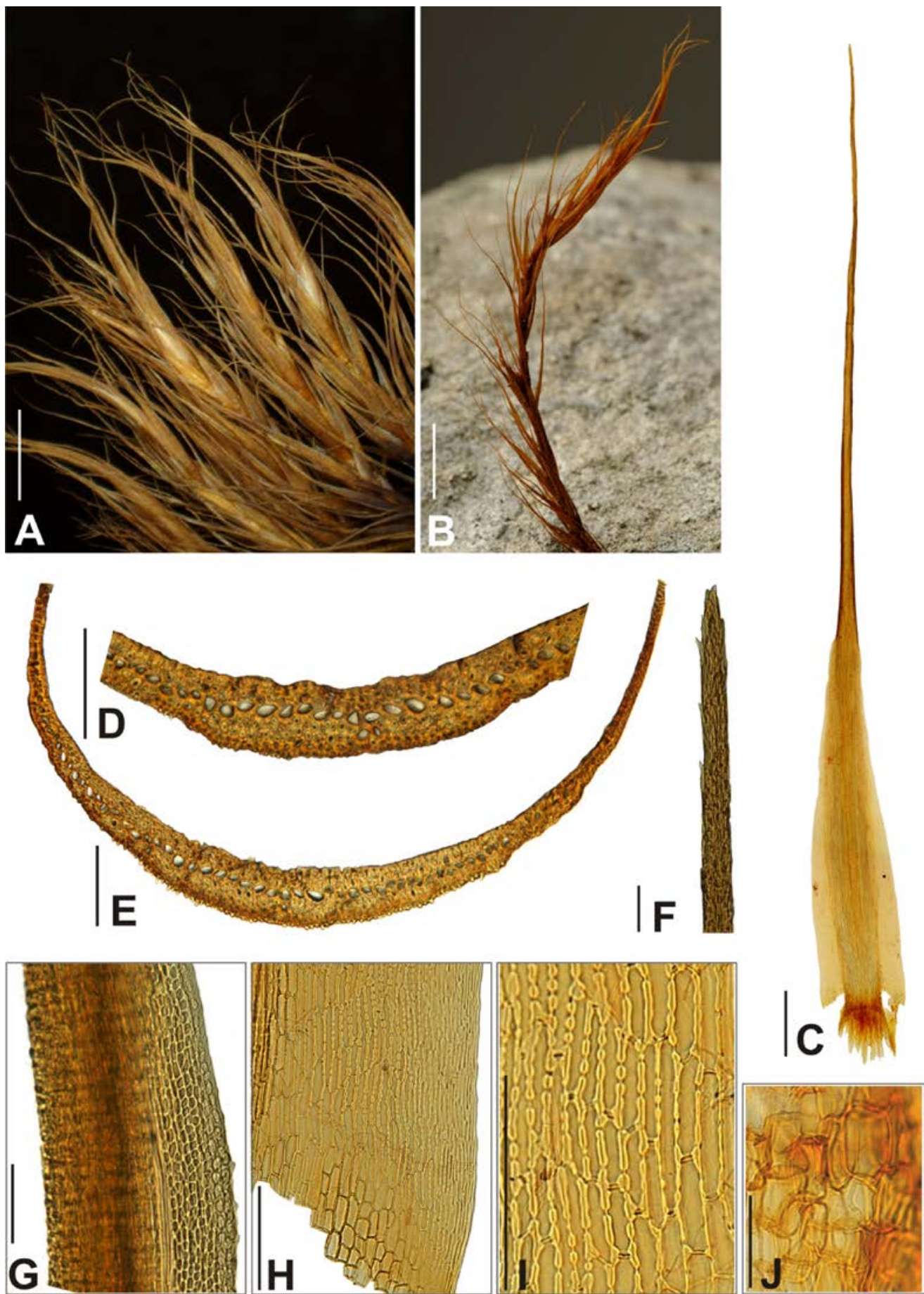

Fig. 2. Chorisodontium aciphyllum (Hook.f. \& Wilson) Broth. A - habit, B - single shoot, C - leaf, D \& E - leaf transverse sections, F - leaf apex, G - upper leaf cells, H \& I - basal cell, J - alar cells. All from Schwabe 32 (KRAM, isolectotype of Dicranodontium schwabei Thér. \& Herzog). Scale bars: A \& B $-1 \mathrm{~cm}$; C $-1 \mathrm{~mm}$; D-J $-100 \mu \mathrm{m}$. 
Dicranodontium Schwabei Herz. et Thér. Waldhagen - Chile Pumiliogrenze 1200 m № 32 leg: Schwabe 1.1.38 det: Thériot, X.38' - JE-Herzog!; ISOLECTOTYPES: KRAM!, PC-Thériot! First synonymised by Müller (2002: 446).

\section{PhytogeOGRAPHICAL AND ECOLOGICAL CONSIDERATIONS}

Chorisodontium aciphyllum is a south-pantemperate species with a maximum of occurrence in the Nothofagus zone in southern South America, where it is widespread and locally common from the Valdivian region at lat. $c a 38^{\circ} \mathrm{S}$ in Chile to Cape Horn and the Falkland Islands (Greene 1986; Hyvönen 1991), extending northwards to the province of Bio-Bio in central Chile (Ireland et al. 2017) and Islas de Juan Fernández at lat. ca 333' S (Robinson 1975) and southwards to subantarctic South Georgia (Bell 1973). It is frequent and locally abundant in the northern maritime Antarctic where it extends to lat. $65^{\circ} 19^{\prime} \mathrm{S}$ on Green Island in the Berthelot Islands archipelago off the Graham Coast (Ochyra et al. 2008). In the Subantarctic, Ch. aciphyllum exhibits a typical amphiatlantic disjunction, recurring in Îles Kerguelen at lat. $49^{\circ} 30^{\prime} \mathrm{S}$ and long. $69^{\circ} 50^{\prime} \mathrm{E}$ (Cardot 1916), on the highly isolated Île Amsterdam at lat. $37^{\circ} 50^{\prime} \mathrm{S}$ and long. $71^{\circ} 30^{\prime} \mathrm{E}$ in the South Indian Ocean (Bescherelle 1875), and on Tristan da Cunha at lat. $37^{\circ} \mathrm{S}$ and long. $12^{\circ} \mathrm{W}$ in the South Atlantic Ocean (Dixon 1960). Finally, Ch. aciphyllum was recorded once in the South Island of New Zealand (Bartlett \& Frahm 1983).

Ecologically, Chorisodontium aciphyllum is an exceptional species owing to its peat-forming abilities. Along with Polytrichum strictum Brid. it is the main component of semi-ombrotrophic peat banks which develop on gentle, well drained slopes (Lewis Smith \& Gimingham 1976; Collins 1976a; Fenton \& Lewis Smith 1982). They reach to $3 \mathrm{~m}$ in depth and are a unique element of the vegetation cover of subantarctic South Georgia and in some areas in the maritime Antarctic, for example in the South Orkney Islands (Lewis Smith 1972; Collins 1976b) and the Argentine Islands in the Graham Land (Lewis Smith \& Corner 1973).
These peat deposits are of particular importance in palaeoecological studies and in the reconstruction of climate history of this part of the austral polar region (Birkenmajer et al. 1985; Van der Putten et al. 2004, 2009; Roberts et al. 2017). On the South American mainland Ch. aciphyllum grows in a broad range of habitats, including rocks, humus, stony ground, mineral soil and often epiphytically on the lower part of tree trunks, generally in dry to moist sites.

ACKNOWLEDGEMENTS. The authors are indebted to the Curators of the herbaria at BM, E, JE, MANCH and PC for making specimens available for examination. Thanks are due to Rod D. Seppelt, Arundel, Australia, for checking the English, and to James R. Shevock, San Francisco, USA, and Robert R. Ireland, Ottawa, Canada, for valuable comments and suggestions. The work of H. Bednarek-Ochyra and R. Ochyra was financially supported through the statutory fund of the W. Szafer Institute of Botany of the Polish Academy of Sciences and the work of V. Plášek is part of research projects by EU structural funding Operational Programme Research and Development for Innovation, project No. CZ.1.05/2.1.00/19.0388 and the National Feasibility Programme I of the Czech Republic Project LO1208.

\section{REFERENCES}

Bartlett J. K. \& Frahm J.-P. 1983. Notes on Campylopus and Chorisodontium from New Zealand. J. Bryol. 12: 365-382.

Bell B. G. 1973. A synoptic flora of South Georgian mosses: II. Chorisodontium, Dicranoloma, Dicranum, Platyneurum and Conostomum. Brit. Antarct. Surv. Bull. 37: 33-52.

Bell B. G. 1977. Notes on Antarctic bryophytes: IX. A previously unreported botanical collection made on South Georgia during the German International Polar-Year Expedition, 1882-82. Brit. Antarct. Surv. Bull. 46: 137-139.

Bescherelle É. 1875. Note sur les mousses des îles SaintPaul et d'Amsterdam. Compt. Rend. Hebd. Séances Acad. Sci. 81: 720-725.

Birkenmajer K., Ochyra R., Olsson I. U. \& Stuchlik L. 1985. Mid-Holocene radiocarbon-dated peat at Admiralty Bay, King George Island (South Shetland Islands, West Antarctica). Bull. Polish Acad. Sci., Earth Sci. 33: 7-13.

Cardot J. 1916. Note sur des mousses de Kerguelen. Bull. Mus. Hist. Nat. 22: 336-341.

Collins N. J. 1976a. Growth and population dynamics of the moss Polytrichum alpestre in the maritime Antarctic. Oikos 27: 389-401. 
Collins N. J. 1976b. The development of moss-peat banks in relation to changing climate and ice cover on Signy Island in the maritime Antarctic. Brit. Antarct. Surv. Bull. 43: 85-102.

Dixon H. N. 1960. Mosses of Tristan da Cunha. In: E. CHristoPHERSEN (ed.), Results of the Norwegian Scientific Expedition to Tristan da Cunha 1937-1938. 48. Kommissjon hos H. Aschehoug \& Co. (W. Nygaard), Oslo.

Fenton J. H. C. \& Lewis Smith R. I. 1982. Distribution, composition and general characteristics of the moss banks of the maritime Antarctic. Brit. Antarct. Surv. Bull. 51: 215-236.

Frahm J.-P. 1981a. Taxonomische Notizen zur Gattung Campylopus X. Lindbergia 7: 27-31.

FraHm J.-P. 1981b. Bestimmungsschlüssel und Illustrationen zu Gattung Chorisodontium Broth. Herzogia 5: 499-516.

Frahm J.-P. 1987. A revised list of Campylopus species of the world. Bryol. Beitr. 7: 1-117.

Frahm J.-P. 1989. The genus Chorisodontium (Dicranaceae, Musci) in the Neotropics. Trop. Bryol. 1: 11-24.

Frahm J.-P. 1991. Dicranaceae: Campylopodioideae, Paraleucobryoideae. Fl. Neotrop. Monogr. 54: 1-238.

Frahm J.-P. 1997. A taxonomic revision of Dicranodontium (Musci). Ann. Bot. Fenn. 34: 179-204.

GreEne D. M. 1986. A conspectus of the mosses of Antarctica, South Georgia, the Falkland Islands and southern South America. British Antarctic Survey, Cambridge.

Herzog TH. 1939. Verzeichnis der gesammelten Bryophyten. In: Th. Herzog, G. H. Schwabe \& E. Schwabe, Zur Bryophytenflora Südchiles. (Aus dem südchilenischen Küstengebiet. Beitrag 7). Beih. Bot. Centralbl., Abt. B 60: 1-35.

HoOKer J. D. \& WILSON W. 1844. Musci antarctici; being characters with brief descriptions of the new species of mosses discovered during the voyage of H. M. discovery ships, Erebus and Terror, in the southern circumpolar regions, together with those of Tasmania. London J. Bot. 3: 533-556.

HyvönEn J. 1991. Chorisodontium (Dicranaceae, Musci) in southern South America. Ann. Bot. Fenn. 28: 247-258.

Ireland R. R., Bellolio G., Larraín J. \& Rodríguez R. 2017. Studies on the moss flora of the Bío-Bío Region of Chile: part 3. PhytoKeys 77: 1-20.

Lewis Smith R. I. 1972. Vegetation of the South Orkney Islands with particular references to Signy Island. Brit. Antarct. Surv. Sci. Rep. 68: 1-124 + pls 1-6.

Lewis Smith R. I. \& Corner R. W. M. 1973. Vegetation of the Arthur Harbout-Argentine Islands region of the Antarctic Peninsula. Brit. Antarct. Surv. Bull. 33/34: 89-122.

Lewis Smith R. I. \& Gimingham C. H. 1976. Classification of cryptogamic communities in the maritime Antarctic. Brit. Antarct. Surv. Bull. 43: 25-47.

McNeill J., Barrie F. R., Buck W. R., Demoulin V., Greuter W., Hawksworth D. L., Herendeen P. S., Knapp S.,
Marhold K., Prado J., Prud'homme van Reine W. F., Smith G. F., Wiersema J. H. \& Turland N. J. (eds), 2012. International Code of Nomenclature for algae, fungi, and plants (Melbourne Code), adopted by the Eighteenth International Botanical Congress Melbourne, Australia, July 2011. Regnum Vegetabile 154. Koeltz Scientific Books, Königstein.

Mitten G. 1869. Musci austro-americani, sive Enumeratio muscorum omnium austro-americanorum mihi hucusque cognitorum, eorum praecipue in terris amazonicis andinisque Ricardo Spruceo lectorum. J. Linn. Soc., Bot. 12: 1-659.

MüLlER F. 2002. New records and new synonyms for the southern South American moss flora. Nova Hedwigia 74: 445-450.

OCHYRA R. 1993a. Antipodal mosses: I. A revision of the genus Holodontium (Seligeriaceae). Fragm. Florist. Geobot. 38: 75-98.

OCHYRA R. 1993b. The taxonomic status of Blindia skottsbergii (Musci, Seligeriaceae). Fragm. Florist. Geobot. 38: 503-508.

OCHYRA R. 1994. Antipodal mosses: II. The identity of Ditrichum perporodictyon (Musci, Ditrichaceae). Fragm. Florist. Geobot. 39: 113-116.

OChYRA R. 1996. Antipodal mosses: V. On Distichium austrogeorgicum (Ditrichaceae). Fragm. Florist. Geobot. 41: 335-338.

OCHYRA R. 1999. The identity of some forms of Antarctic mosses. Fragm. Florist. Geobot. 44: 511-514.

OCHYRA R. 2003. A nomenclatural comment on the northern Andean Chorisodontium (Dicranaceae) and citation of Hooker names. J. Bryol. 25: 66-68.

Ochyra R., Lewis Smith R. I. \& BednareK-Ochyra H. 2008. The illustrated moss flora of Antarctica. Cambridge University Press, Cambridge.

Roberts S. J., Monien P., Foster L. C., Loftfield J., Schnetger B., Pearson E. J., Hocking E. P., Fretwell P., Ireland L., Ochyra R., Haworth A. R., Allen C. S., Moreton S. G., Davies S. J., Brumsack H.-J., Bentley M. J. \& Hodgson D. A. 2017. Past penguin colony responses to explosive volcanism on the Antarctic Peninsula. Nature Comm. 8: Article number-14914: pp. 1-16. DOI: 10.1038/ncomms 14914 .

Robinson H. 1975. The mosses of Juan Fernandez Islands. Smithsonian Contr. Bot. 27: i-iv + 1-88.

Roivainen H. \& Bartram E. B. 1937. Bryological investigations in Tierra del Fuego. Ann. Bot. Soc. Zool.-Bot. Fenn. "Vanamo" 9(2): i-x + 1-58.

Van der Putten N., Stieperaere H., Verbruggen C. \& OCHYRA R. 2004. Holocene palaeoecology and climate history of South Georgia (sub-Antarctica) based on a macrofossil record of bryophytes and seeds. Holocene 14: $382-392$. 
Van der Putten N., Verbruggen C., Ochyra R., Spassov S., de Beaulieu J.-L., De Dapper M., Hus J \& Thouveny N. 2009. Peat bank growth, Holocene palaeoecology and climate history of South Georgia (sub-Antarctica), based on a botanical macrofossil record. Quatern. Sci. Rev. 28: 65-79.

WiJk R. van der, Margadant W. D. \& Florschütz P. A. 1959. Index Muscorum. 1 (A-C). Regnum Vegetabile 17.
International Bureau for Plant Taxonomy and Nomenclature of the International Association of Plant Taxonomy, Utrecht.

Wijk R. van der, Margadant W. D. \& Florschütz P. A. 1969. Index Muscorum. 5 (T-Z, Appendix). Regnum Vegetabile 65. International Bureau for Plant Taxonomy and Nomenclature of the International Association of Plant Taxonomy, Utrecht. 